\title{
Noncanonical Constitutive Androstane Receptor Signaling in Gene Regulation
}

\author{
Yuliya A. Pustylnyak ${ }^{1}$, Lyudmila F. Gulyaeva ${ }^{1,2}$ and Vladimir O. Pustylnyak 1,2,*(D) \\ 1 Zelman Institute for the Medicine and Psychology, Novosibirsk State University, Pirogova street, 1, \\ 630090 Novosibirsk, Russia; yupustylnyak@mail.ru (Y.A.P.); gulyaeva@niimbb.ru (L.F.G.) \\ 2 Federal Research Center of Fundamental and Translational Medicine, Timakova street, 2/12, \\ 630117 Novosibirsk, Russia \\ * $\quad$ Correspondence: pustylnyak@post.nsu.ru; Tel.: +7-(383)-363-40-08
}

Received: 17 July 2020; Accepted: 10 September 2020; Published: 14 September 2020

\begin{abstract}
The constitutive androstane receptor (CAR, NR1I3) is extremely important for the regulation of many physiological processes, especially xenobiotic (drug) metabolism and transporters. CAR differs from steroid hormone receptors in that it can be activated using structurally unrelated chemicals, both through direct ligand-binding and ligand-independent (indirect) mechanisms. By binding to specific responsive elements on DNA, CAR increases the expression of its target genes encoding drug-metabolizing enzymes and transporters. Therefore, CAR is mainly characterized as a ligand-dependent or ligand-independent transcription factor, and the induction of gene expression is considered the canonical mode of CAR action. Consistent with its central role in xenobiotic metabolism, CAR signaling includes a collection of mechanisms that are employed alongside the core transcriptional machinery of the receptor. These so-called noncanonical CAR pathways allow the receptor to coordinate the regulation of many aspects of cell biology. In this mini-review, we review noncanonical CAR signaling, paying special attention to the role of CAR in energy homeostasis and cell proliferation.
\end{abstract}

Keywords: CAR; noncanonical signaling; gene regulation; energy homeostasis; cell proliferation

\section{Introduction}

The constitutive androstane receptor (CAR, NR1I3) is a member of the nuclear receptor superfamily (NR), which includes steroid, retinoid, and thyroid hormone receptors [1]. Members of this superfamily play key roles in almost all aspects of development and physiology, as they function as ligand-activated transcription factors. CAR belongs to the vitamin D receptor subfamily of the nuclear receptor superfamily [1]. CAR is mostly expressed in the liver [2].

CAR, similar to most members of the superfamily, has a classic domain structure that includes a DNA-binding domain (DBD) with two zinc fingers and a conserved ligand-binding domain (LBD). DBD is involved in the interaction of the receptor with short stretches of DNA, termed response elements, in the regulatory regions of target genes. LBD serves as a ligand docking site and also contains dimerization motifs and transcription activation domains, such as the region of activation function 2 (AF-2) [3]. The AF-2 region of CAR contains a very stable helix H11 in its structure. Therefore, AF-2 is constantly fixed in the active conformation [4]. Interaction with ligands further enhances receptor activity [5].

CAR is activated by various chemical compounds that are related to drugs, pesticides, food flavonoids, polyphenols, etc. [6,7]. The half maximal effective concentrations (EC50s) for ligand binding to CAR range from the nanomolar to micromolar range, suggesting that even low-affinity binding of ligands to CAR can cause strong cellular signals. The ability of some 
ligands to bind to the receptor remains a matter of discussion, since only two compounds1,4-bis-[2-(3,5-dichloropyridyloxy)] benzene (ТСРОВOP) and 6-(4-chlorophenyl) imidazo-[2,1-b][1,3] thiazole-5-carbaldehyde-O- (3,4-dichlorobenzyl)oxime (CITCO)—display a direct interaction with the CAR ligand-binding pocket. The affinity of these compounds for CAR varies significantly between species. TCPOBOP activates CAR in mice, but not in humans, while CITCO has the opposite effect. In addition, CAR can be activated by chemical compounds indirectly, through signal transduction pathways. A classic example of an indirect CAR activator is phenobarbital (PB), which triggers a signaling cascade in hepatocytes that leads to the CAR active state [8].

CAR was originally characterized as a xenosensor that induces the expression of the CYP2B gene (cytochrome $\mathrm{P} 450$ of the 2B subfamily), which is involved in the biotransformation of a wide range of xenobiotics, including drugs $[9,10]$. It was later demonstrated that CAR regulates many genes encoding key enzymes of drug and xenobiotic metabolism, including phase I (CYP2B, CYP3A, etc.), phase II (SULT, UGT, and GST), and transporter genes [11]. Drug-metabolizing genes are regulated by CAR according to the canonical mechanism: CAR binds to the phenobarbital (PB)-responsive enhancer module (PBREM) in the promoter of the target gene, activating its expression $[9,10]$.

It was previously shown that the activation of CAR has a pleiotropic effect on physiological and pathological processes: activation of CAR alters glucose homeostasis and lipid metabolism and also leads to cell cycle disturbances and the inhibition of apoptosis. Using RNA-seq technology, it was found that CAR activation causes a change in the expression of more than 2000 genes [12]. CAR activation can lead to both the induction and inhibition of gene expression. For example, the activation of CAR leads to a decrease in the expression of gluconeogenesis genes in the liver $[13,14]$. In addition, CAR activation significantly enhances hepatocyte proliferation, followed by liver hyperplasia [15]. Often, the regulation of processes, other than drug metabolism and elimination, is carried out by noncanonical CAR signaling. This mini-review contains the recent progress in our understanding of noncanonical CAR signaling and how it coordinates the regulation of several aspects of the biochemistry of cells.

\section{Activation of CAR Nuclear Translocation}

Compared to other nuclear receptors, CAR has a unique activation mechanism, which includes both nuclear translocation and nuclear activation $[16,17]$. In addition, another feature of the activation of CAR is the fact that a number of compounds that activate the transcriptional activity of the receptor are not its ligands [18]. Therefore, the direct interaction of CAR with these chemical compounds is not necessary for its activation [19]. In the inactive state, CAR is located in the cell cytoplasm in a complex with several proteins: heat shock protein 90 (HSP90), cytoplasmic CAR retention protein (CCRP), and the membrane-associated subunit of protein phosphatase $1 \beta$ (PPP1R16A) [20-23]. In addition, this complex is stabilized in an inactive state by the HSP70 chaperone protein [24]. When CAR interacts with a ligand in the cytoplasm, the chaperone proteins HSP90 and CCRP, which maintain the inactive state of the receptor, dissociate and CAR translocates to the nucleus.

Phenobarbital (PB) is a classic example of an indirect CAR activator, which exerts its activating effect through signal transduction pathways. It has been demonstrated that the activation of CAR using $\mathrm{PB}$ is mainly associated with its nuclear translocation. Moreover, nuclear translocation of the receptor is reduced by a protein phosphatase 2A inhibitor [10]. This suggests that the nuclear translocation of CAR, caused by an indirect activator, is associated with the signaling pathway in which dephosphorylation of the receptor protein occurs. It was further shown that activation of the protein kinase ERK1/2 leads to the inhibition of CAR nuclear translocation and inhibition of the transcription of CAR target genes. Inhibition of the ERK1/2 signaling pathway enhanced the induction of CAR target genes [25]. To activate hCAR nuclear translocation under the action of $\mathrm{PB}$, phosphorylation of the receptor in Thr38 (Thr48 in mCAR) is necessary [26]. In 2013, it was convincingly demonstrated that PB exerts its activation effect through a pathway involving the epidermal growth factor receptor (EGFR) [8]. It has been shown that PB is able to bind to EGFR and block the activation of its signaling pathway. This 
leads to the activation of protein phosphatase 2A (PP2A), which dephosphorylates CAR to the Thr38 position and triggers its nuclear translocation.

\section{Canonical CAR Pathway}

Through the canonical signaling pathway, CARs increase the expression of target genes encoding drug-metabolizing enzymes and transporters. The marker CAR target gene is CYP2B, whose expression upon receptor activation increases to a much greater extent than that of other genes. In 1995, it was demonstrated that the response to $\mathrm{PB}$ is associated with a nucleotide sequence located in the region of -2318/-2155 bp in the CYP2B2 gene promoter in rat hepatocyte cultures [27]. Later, in experiments on cultures of mouse hepatocytes conducted in the laboratory of M. Negishi, a 51 bp sequence was identified in the regulatory region of the Cyp $2 b 10$ gene. The introduction of mutations in this region led to a loss of sensitivity to PB. The sequence was termed PBREM [28]. The sequence has also been found in other species, such as rats and humans [29]. PBREM consists of two nuclear receptor binding sites (NR1 and NR2) and a nuclear factor 1 binding site (NF1) [9]. NR1 and NR2 contain incomplete direct repeats separated by four base pairs (DR4). The sequence of NR1 (5'-TGTACTTTCCTGACCT-3') in the promoter region of $C Y P 2 B$ genes in different species is the most conserved [30].

In a further series of experiments, using affinity chromatography with an NR1 oligonucleotide as a ligand, CAR was identified as a key induction factor under the action of phenobarbital [9]. It was shown that in fractions obtained from extracts of the liver nuclei of mice treated with PB, CAR accumulates together with retinoid $X$ receptor ( $R X R, N R 2 B)$. In the nucleus, CAR heterodimerizes with $R X R$ and recruits coactivators, which leads to interactions with PBREM in the regulatory regions of target gene promoters [19]. In 2003, an additional CAR-specific regulatory element was identified in the CYP2B6 gene promoter. This regulatory sequence was termed the xenobiotic responsive enhancer module (XREM), and is located in the region of $-8500 \mathrm{bp}$ in the promoter of CYP2B6 gene [31]. XREM contains a cluster of CAR binding sites, which, by analogy with the NR1 and NR2 of PBREM, were termed NR3-NR8. Both PBREM and XREM are required for maximum activation of the CYP2B6 gene in human hepatocytes.

The main function of coactivators is to alter the chromatin structure, which facilitates the interaction of the general transcription apparatus for induction of transcription of CAR target genes. The key role among coactivators belongs to Steroid Receptor Co-activator-1 (SRC-1), Glucocorticoid Receptor Protein-1 (GRIP-1), and Proliferator-activated receptor Gamma Coactivator-1 alpha (PGC-1 $\alpha$ ) [32-35]. In vitro, it was shown that the transcription factor Sp1 can act as a coactivator of CAR in the upregulation of CYP2B gene expression [31].

According to this canonical mechanism, the activation of CAR leads to an increase in the expression of genes involved in the metabolism and elimination of a wide range of xenobiotics. These genes include members of the cytochrome P450 superfamily, glutathione-S-transferases (GSTs), sulfotransferases (SULTs), UDP-glucuronyltransferases (UGTs), and transporters [11,36].

\section{Noncanonical CAR Signaling in Gluconeogenic Gene Regulation}

Recent studies have demonstrated new CAR functions in various cell processes, for example, glucose metabolism and the regulation of hepatocyte proliferation. Many CAR functions in the liver, other than the regulation of drug-metabolizing genes, are mediated by noncanonical signaling and result in the downregulation of gene expression. The most studied is the CAR-mediated downregulation of gluconeogenesis genes. It is well-known that the use of $\mathrm{PB}$ in patients with diabetes leads to a decrease in blood glucose [37]. It was demonstrated that $\mathrm{PB}$ downregulates the expression of genes that encode rate-limiting enzymes of hepatic gluconeogenesis: phosphoenolpyruvate carboxykinase (PEPCK) and glucose-6-phosphatase (G6Pase) in a CAR-dependent manner [38]. In addition, CAR activation reduces hyperglycemia and increases insulin sensitivity in mice with metabolic disorders [39-41]. Given the important effects of CAR activation on metabolic processes, CAR can be considered an attractive therapeutic molecular target for the treatment of metabolic disorders. 
In recent years, several studies have been carried out that have described in detail three possible mechanisms underlying the regulation of gluconeogenesis by CAR activators. In these experiments, it was demonstrated that CAR is able to regulate the expression of gluconeogenesis genes via noncanonical pathways involving protein-protein interactions. Insulin has an inhibitory effect on the transcription of the G6Pase and PEPCK genes in which rate-limiting enzymes are encoded. The expression of these genes is regulated by the transcription factor forkhead box O1 (FoxO1), which binds to the insulin-responsible sequence (IRS). Insulin activates protein kinase B (Akt), which phosphorylates FoxO1. Such phosphorylation leads to the transfer of FoxO1 from the nucleus to the cytoplasm and its proteosomal degradation [42]. In vitro and in vivo experiments showed that activated CAR binds to FoxO1, thereby blocking its interaction with IRS in the regulatory regions of the PEPCK and G6Pase genes $[43,44]$ (Figure 1A).

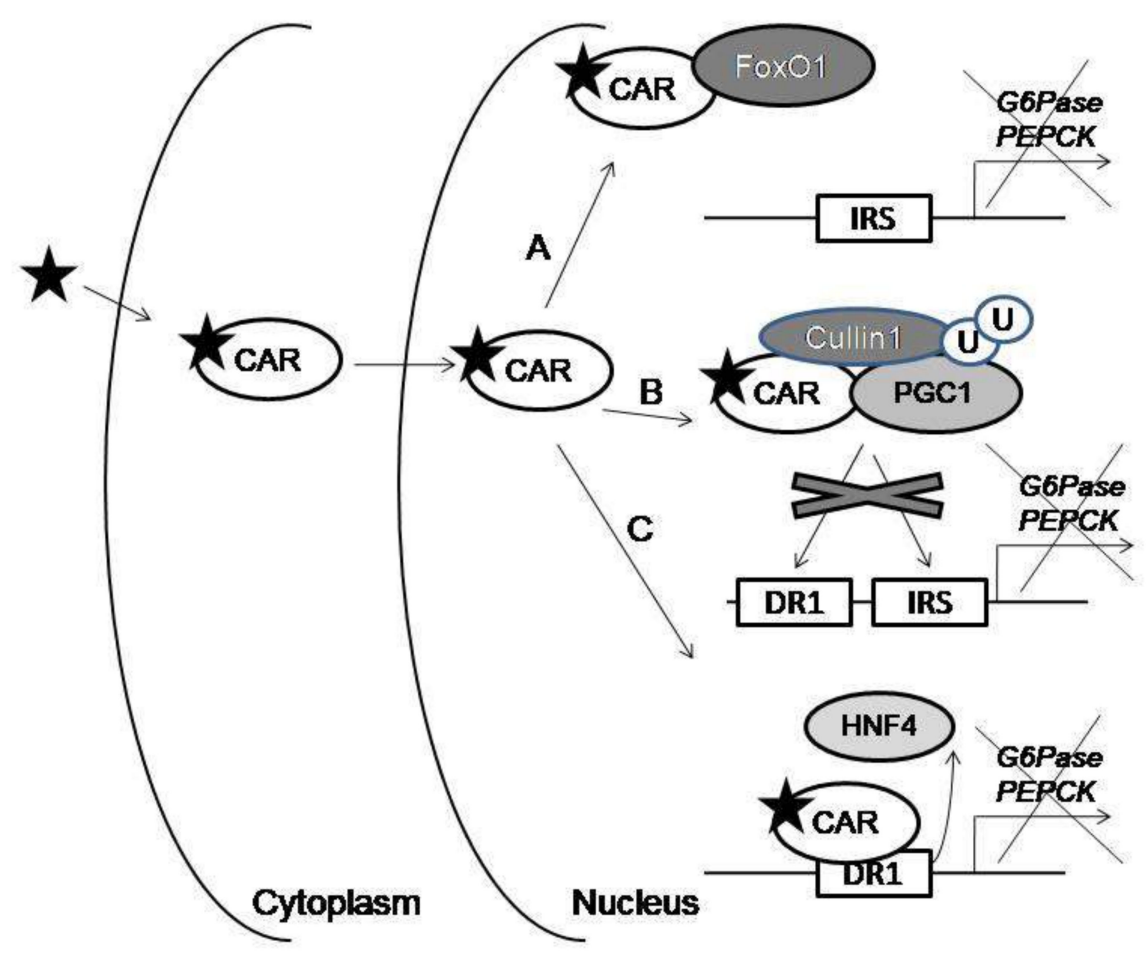

Figure 1. Noncanonical mechanisms of the constitutive androstane receptor (CAR)-mediated suppression of gene expression. When CAR interacts with a ligand in the cytoplasm, CAR translocates to the nucleus. (A) Activated CAR binds to forkhead box O1 (FoxO1), thereby blocking its interaction with the insulin-responsible sequence (IRS) in the gene promoters. (B) Activated CAR serves as an adapter protein for the recruitment of Proliferator-activated receptor Gamma Coactivator-1 alpha (PGC1 $\alpha$ ) into the complex with E3 ligase Cullin1, where PGC1 $\alpha$ undergoes ubiquitination and subsequently, proteasome degradation. (C) Activated CAR competes with hepatic nuclear factor- $4 \alpha$ (HNF4 $\alpha$ ) for binding to DR1.

PGC1a is also a major regulator of gluconeogenesis [45]. FoxO1 and PGC1a cooperate to induce gluconeogenesis by activating PEPCK and G6Pase gene expression [46]. It was previously shown that CAR suppresses the expression of gluconeogenic genes through post-translational regulation, subcellular localization, and degradation of the PGC1 $\alpha$ coactivator (Figure 1B). Activated CAR translocates to the nucleus and serves as an adapter protein for the recruitment of PGC1 $\alpha$ into the complex with E3 ligase Cullin1 [47]. After that, PGC1 $\alpha$ undergoes ubiquitination and, subsequently, proteasome degradation. It has been suggested that such negative regulation of PGC1 $\alpha$ by CAR could be a cellular adaptive mechanism for adapting to energy-limited conditions. Therefore, the protein-protein interactions described above underlie the suppression of the expression of key genes involved in gluconeogenesis in response to the action of CAR activators. 
In addition to FoxO1, other transcription factors, such as hepatic nuclear factor- $4 \alpha$ (HNF4 $\alpha$ ), regulate G6Pase and PEPCK gene expression [48]. Both genes contain functional HNF4 $\alpha$-binding sites (DR1 motif) in their regulatory regions. The third noncanonical mechanism of the regulation of gluconeogenic genes mediated by CAR is associated with the transcription factor HNF $4 \alpha$. CAR first competes with HNF4 $\alpha$ for binding to DR1. The binding of activated CAR to DR1 leads to the repression of transcription of the G6Pase and PEPCK genes [49-51] (Figure 1C). Secondly, CAR competes with HNF- $4 \alpha$ for a limited pool of common coactivators, including PGC- $1 \alpha$, which dissociate from promoters of the HNF- $4 \alpha$ target genes [49].

Recently, the existence of gender differences in CAR-mediated regulation of energy homeostasis has been demonstrated [52]. Understanding the role of sex hormones in the CAR-mediated mechanism underlying sexual dimorphism in glucose homeostasis may facilitate the development of sex-specific therapy for metabolic diseases.

\section{Noncanonical CAR Signaling in Hepatocyte Proliferation}

It has been known for a long time that the activation of CAR is accompanied by a strong proliferative effect in hepatocytes [53-55]. This fact gave grounds to consider CAR as a therapeutic target for partial liver resection [56]. Moreover, in 2016 it was demonstrated that in CAR-/- mice, liver failure occurs even after standard hepatectomy ( $2 / 3$ of the liver). Pharmacological activation of CAR in wild-type mice can improve liver regeneration and inhibit the development of liver failure during extreme resections (more than $85 \%$ of the organ), and this effect is mediated by a decrease in the level of p21 protein [57]. Several studies have demonstrated a possible mechanism for CAR-mediated regulation of p21 levels. A key role in the activation of liver hyperplasia is played by promitogenic protein cMyc signaling, which promotes hepatocyte proliferation [58]. However, the question of how CAR regulates the level of cMyc in response to ТСРОВОР treatment remained has unanswered for a long time, since a functional CAR binding site has not yet been identified in the $c M y c$ gene promoter [58]. It has recently been demonstrated that PB is able to reduce miR-122 in mouse livers [59]. Moreover, in the same work, it was shown that PB inhibits the transactivation of the pri-mir-122 promoter. This suggests that the suppression of miR-122 upon exposure to PB occurs at the level of transcription. MiR-122 is a liver-specific miRNA that accounts for about 70\% of the miRNA population in this organ [60] and plays a significant role in many physiological processes in the liver [61]. MiR-122 regulates cMyc through regulation of the level of transcription factor E2f1 [62]. Transcription of pri-miR-122, the precursor of miR-122, is regulated by hepatic transcription factors, including HNF4 $\alpha[63,64]$. HNF $4 \alpha$ increases the miR-122 level by directly binding to the regulatory region of pri-miR-122 [64]. As was the case with the regulation of gluconeogenic genes, it was demonstrated that CAR decreases the level of miR-122, which is the molecular target of the transcription factor HNF $4 \alpha$, competing with HNF $4 \alpha$ for binding to the DR1 motif in the pri-miR-122 promoter [65]. The decrease in miR-122 caused by CAR activation is accompanied by an increase in E2f1, as well as its accumulation on the $c M y c$ promoter. CAR activation decreases miR-122 through the suppression of HNF $4 \alpha$ transcriptional activity on the pri-miR-122 promoter and indirectly regulates cMyc. Moreover, a CAR-mediated decrease in miR-122 could produce activation of the Akt through initiation of the cMyc-FoxM1-Nedd4-1-PTEN pathway [66] and subsequent Akt-Foxo1-mediated decrease of p21 [67]. Therefore, the noncanonical CAR signaling in gene regulation, based on competition with HNF4a for the DR1, appears to be involved not only in the regulation of gluconeogenesis but also in the regulation of hepatocyte proliferation.

Understanding the molecular mechanisms of CAR-mediated induction of hepatocyte proliferation is very important, since the loss of the ability of hepatocytes to maintain a balance between growth stimulating and inhibitory signals may be a trigger for tumor promotion. In 2004, the role of CAR in hepatocarcinogenesis was first demonstrated using wild-type and CAR -/- mice. It has been demonstrated that chronic administration of PB induces liver tumors in wild-type mice [68]. Recently, it was shown that the hepatocarcinogenic effect of CAR activators appears in combination with $\beta$-catenin $[69,70]$. There is evidence that CAR-mediated activation of the Akt pathway causes 
redistribution of $\beta$-catenin from the cytoplasm to the nucleus in dividing hepatocytes [71]. CAR activates yes-associated protein (YAP) signaling, which may also be involved in CAR-mediated liver carcinogenesis [72,73]. The question of how liver tumors are promoted upon activation of CAR remains open.

\section{Conclusions}

CAR was originally characterized as a xenosensor that, when activated by chemical compounds, acts as a transcription factor for the activation of drug-metabolizing genes and transporter genes. However, intensive studies have recently demonstrated its pleiotropic effects on cellular processes, including gluconeogenesis and hepatocyte proliferation. It is likely that the processes, such as drug metabolism, gluconeogenesis, and hepatocyte proliferation, triggered by CAR activation, are interrelated. Thus, liver hyperplasia in response to xenobiotic exposure may be part of the adaptation process: an increase in the liver is caused by the need for more detoxification enzymes. Proliferating hepatocytes require a building material; therefore, CAR-mediated reduction of gluconeogenesis can lead to the redistribution of glucose-6-phosphate into the pentose phosphate pathway. The pentose phosphate pathway provides hepatocytes with ribose for the synthesis of nucleotides, which are precursors for the biosynthesis of nucleic acids. At the same time, CAR-mediated suppression of gluconeogenesis may contribute to the maintenance of the required level of NADPH, which is also a product of the pentose phosphate pathway, to perform the protective function of drug metabolism under conditions of limited energy consumption. Nevertheless, several researchers have suggested CAR as a therapeutic target for glucose level correction or improving liver regeneration. This necessitates a better understanding of the signaling mechanisms that are triggered when CAR is activated, because these can have a profound effect on numerous processes, from drug-drug interactions and toxicity responses to tumor promotion. Studies conducted in recent years have shown that many of the effects of CAR are mediated through noncanonical signaling. In this regard, knowledge of such "nontraditional" mechanisms of gene regulation with the participation of CAR is very important. In our opinion, subsequent discoveries over the next few years will be made outside the "canonical" mechanism of CAR-mediated gene regulation.

Author Contributions: Conceptualization, Y.A.P., L.F.G., and V.O.P.; original draft preparation, Y.A.P. and V.O.P.; review and editing, L.F.G. and V.O.P. All authors have read and agreed to the published version of the manuscript.

Funding: This work was supported by the Russian Science Foundation [grant number, 18-15-00021].

Acknowledgments: We thank our colleagues for their support.

Conflicts of Interest: There are no conflict of interest for any of the authors.

\section{References}

1. Alexander, S.P.; Cidlowski, J.A.; Kelly, E.; Marrion, N.V.; Peters, J.A.; Faccenda, E.; Harding, S.D.; Pawson, A.J.; Sharman, J.L.; Southan, C.; et al. THE CONCISE GUIDE TO PHARMACOLOGY 2017/18: Nuclear hormone receptors. Br. J. Pharmacol. 2017, 174, S208-S224. [CrossRef] [PubMed]

2. Kakizaki, S.; Yamazaki, Y.; Takizawa, D.; Negishi, M. New insights on the xenobiotic-sensing nuclear receptors in liver diseases-CAR and PXR-. Curr. Drug Metab. 2008, 9, 614-621. [CrossRef] [PubMed]

3. Buchman, C.D.; Chai, S.C.; Chen, T. A current structural perspective on PXR and CAR in drug metabolism. Expert Opin. Drug Metab. Toxicol. 2018, 14, 635-647. [CrossRef] [PubMed]

4. Wright, E.; Busby, S.A.; Wisecarver, S.; Vincent, J.; Griffin, P.R.; Fernandez, E.J. Helix 11 dynamics is critical for constitutive androstane receptor activity. Structure 2011, 19, 37-44. [CrossRef] [PubMed]

5. Xu, R.X.; Lambert, M.H.; Wisely, B.B.; Warren, E.N.; Weinert, E.E.; Waitt, G.M.; Williams, J.D.; Collins, J.L.; Moore, L.B.; Willson, T.M.; et al. A structural basis for constitutive activity in the human CAR/RXRalpha heterodimer. Mol. Cell. 2004, 16, 919-928. [CrossRef]

6. Li, H.; Wang, H. Activation of xenobiotic receptors: Driving into the nucleus. Expert Opin. Drug Metab. Toxicol. 2010, 6, 409-426. [CrossRef] 
7. Molnár, F.; Küblbeck, J.; Jyrkkärinne, J.; Prantner, V.; Honkakoski, P. An update on the constitutive androstane receptor (CAR). Drug Metabol. Drug Interact. 2013, 28, 79-93. [CrossRef]

8. Mutoh, S.; Sobhany, M.; Moore, R.; Perera, L.; Pedersen, L.; Sueyoshi, T.; Negishi, M. Phenobarbital indirectly activates the constitutive active androstane receptor (CAR) by inhibition of epidermal growth factor receptor signaling. Sci. Signal. 2013, 6, ra31. [CrossRef]

9. Honkakoski, P.; Zelko, I.; Sueyoshi, T.; Negishi, M. The nuclear orphan receptor CAR-retinoid X receptor heterodimer activates the phenobarbital-responsive enhancer module of the CYP2B gene. Mol. Cell. Biol. 1998, 18, 5652-5658. [CrossRef]

10. Kawamoto, T.; Sueyoshi, T.; Zelko, I.; Moore, R.; Washburn, K.; Negishi, M. Phenobarbital-responsive nuclear translocation of the receptor CAR in induction of the CYP2B gene. Mol. Cell. Biol. 1999, 19, 6318-6322. [CrossRef]

11. Urquhart, B.L.; Tirona, R.G.; Kim, R.B. Nuclear receptors and the regulation of drug-metabolizing enzymes and drug transporters: Implications for interindividual variability in response to drugs. J. Clin. Pharmacol. 2007, 47, 566-578. [CrossRef] [PubMed]

12. Cui, J.Y.; Klaassen, C.D. RNA-Seq reveals common and unique PXR- and CAR-target gene signatures in the mouse liver transcriptome. Biochim. Biophys. Acta 2016, 1859, 1198-1217. [CrossRef] [PubMed]

13. Yan, J.; Xie, W. A brief history of the discovery of PXR and CAR as xenobiotic receptors. Acta Pharm. Sin. B 2016, 6, 450-452. [CrossRef] [PubMed]

14. Pu, S.; Wu, X.; Yang, X.; Zhang, Y.; Dai, Y.; Zhang, Y.; Wu, X.; Liu, Y.; Cui, X.; Jin, H.; et al. The Therapeutic Role of Xenobiotic Nuclear Receptors against Metabolic Syndrome. Curr. Drug Metab. 2019, 20, 15-22. [CrossRef] [PubMed]

15. Tian, J.; Huang, H.; Hoffman, B.; Liebermann, D.A.; Ledda-Columbano, G.M.; Columbano, A.; Locker, J. Gadd $45 \beta$ is an inducible coactivator of transcription that facilitates rapid liver growth in mice. J. Clin. Investig. 2011, 121, 4491-4502. [CrossRef] [PubMed]

16. Zelko, I.; Negishi, M. Phenobarbital-elicited activation of nuclear receptor CAR in induction of cytochrome P450 genes. Biochem. Biophys. Res. Commun. 2000, 277, 1-6. [CrossRef]

17. Honkakoski, P.; Sueyoshi, T.; Negishi, M. Drug-activated nuclear receptors CAR and PXR. Ann. Med. 2003, 35, 172-182. [CrossRef]

18. Carazo, A.; Dusek, J.; Holas, O.; Skoda, J.; Hyrsova, L.; Smutny, T.; Soukup, T.; Dosedel, M.; Pávek, P. Teriflunomide Is an Indirect Human Constitutive Androstane Receptor (CAR) Activator Interacting With Epidermal Growth Factor (EGF) Signaling. Front Pharmacol. 2018, 9, 993. [CrossRef]

19. Mackowiak, B.; Wang, H. Mechanisms of xenobiotic receptor activation: Direct vs. indirect. Biochim. Biophys. Acta 2016, 1859, 1130-1140. [CrossRef]

20. Zelko, I.; Sueyoshi, T.; Kawamoto, T.; Moore, R.; Negishi, M. The peptide near the C terminus regulates receptor CAR nuclear translocation induced by xenochemicals in mouse liver. Mol. Cell. Biol. 2001, 21, 2838-2846. [CrossRef] [PubMed]

21. Yoshinari, K.; Kobayashi, K.; Moore, R.; Kawamoto, T.; Negish, I.M. Identification of the nuclear receptor CAR:HSP90 complex in mouse liver and recruitment of protein phosphatase 2A in response to phenobarbital. FEBS Lett. 2003, 548, 17-20. [CrossRef]

22. Kobayashi, K.; Sueyoshi, T.; Inoue, K.; Moore, R.; Negishi, M. Cytoplasmic accumulation of the nuclear receptor CAR by a tetratricopeptide repeat protein in HepG2 cells. Mol. Pharmacol. 2003, 64, 1069-1075. [CrossRef]

23. Sueyoshi, T.; Moore, R.; Sugatani, J.; Matsumura, Y.; Negishi, M. PPP1R16A, the membrane subunit of protein phosphatase 1beta, signals nuclear translocation of the nuclear receptor constitutive active/androstane receptor. Mol. Pharmacol. 2008, 73, 1113-1121. [CrossRef]

24. Timsit, Y.E.; Negishi, M. CAR and PXR: The xenobiotic-sensing receptors. Steroids 2007, 72, $231-246$. [CrossRef]

25. Koike, C.; Moore, R.; Negishi, M. Localization of the nuclear receptor CAR at the cell membrane of mouse liver. FEBS Lett. 2005, 579, 6733-6736. [CrossRef]

26. Mutoh, S.; Osabe, M.; Inoue, K.; Moore, R.; Pedersen, L.; Perera, L.; Rebolloso, Y.; Sueyoshi, T.; Negishi, M. Dephosphorylation of threonine 38 is required for nuclear translocation and activation of human xenobiotic receptor CAR (NR1I3). J. Biol. Chem. 2009, 284, 34785-34792. [CrossRef] 
27. Trottier, E.; Belzil, A.; Stoltz, C.; Anderson, A. Localization of a phenobarbital-responsive element (PBRE) in the 5'-flanking region of the rat CYP2B2 gene. Gene 1995, 158, 263-268. [CrossRef]

28. Honkakoski, P.; Negishi, M. Characterization of a phenobarbital-responsive enhancer module in mouse P450 Cyp2b10 gene. J. Biol. Chem. 1997, 272, 14943-14949. [CrossRef] [PubMed]

29. Sueyoshi, T.; Kawamoto, T.; Zelko, I.; Honkakoski, P.; Negishi, M. The repressed nuclear receptor CAR responds to phenobarbital in activating the human CYP2B6 gene. J. Biol. Chem. 1999, 274, 6043-6046. [CrossRef] [PubMed]

30. Sueyoshi, T.; Negishi, M. Phenobarbital response elements of cytochrome P450 genes and nuclear receptors. Annu. Rev. Pharmacol. Toxicol. 2001, 41, 123-143. [CrossRef] [PubMed]

31. Wang, H.; Faucette, S.; Sueyoshi, T.; Moore, R.; Ferguson, S.; Negishi, M.; LeCluyse, E.L. A novel distal enhancer module regulated by pregnane $\mathrm{X}$ receptor/constitutive androstane receptor is essential for the maximal induction of CYP2B6 gene expression. J. Biol. Chem. 2003, 278, 14146-14152. [CrossRef]

32. Muangmoonchai, R.; Smirlis, D.; Wong, S.C.; Edwards, M.; Phillips, I.R.; Shephard, E.A. Xenobiotic induction of cytochrome P450 2B1 (CYP2B1) is mediated by the orphan nuclear receptor constitutive androstane receptor (CAR) and requires steroid co-activator 1 (SRC-1) and the transcription factor Sp1. Biochem. J. 2001, 355, 71-78. [CrossRef] [PubMed]

33. Min, G.; Kemper, J.K.; Kemper, B. Glucocorticoid receptor-interacting protein 1 mediates ligand-independent nuclear translocation and activation of constitutive androstane receptor in vivo. J. Biol. Chem. 2002, 277, 26356-26363. [CrossRef]

34. Shiraki, T.; Sakai, N.; Kanaya, E.; Jingami, H. Activation of orphan nuclear constitutive androstane receptor requires subnuclear targeting by peroxisome proliferator-activated receptor gamma coactivator-1 alpha. A possible link between xenobiotic response and nutritional state. J. Biol. Chem. 2003, 278, 11344-11350. [CrossRef]

35. Xia, J.; Kemper, B. Structural determinants of constitutive androstane receptor required for its glucocorticoid receptor interacting protein-1-mediated nuclear accumulation. J. Biol. Chem. 2005, 280, 7285-7293. [CrossRef] [PubMed]

36. Sugatani, J.; Kojima, H.; Ueda, A.; Kakizaki, S.; Yoshinari, K.; Gong, Q.H.; Owens, I.S.; Negishi, M.; Sueyoshi, T. The phenobarbital response enhancer module in the human bilirubin UDP-glucuronosyltransferase UGT1A1 gene and regulation by the nuclear receptor CAR. Hepatology 2001, 33, 1232-1238. [CrossRef] [PubMed]

37. Lahtela, J.T.; Arranto, A.J.; Sotaniemi, E.A. Enzyme inducers improve insulin sensitivity in non-insulin-dependent diabetic subjects. Diabetes 1985, 34, 911-916. [CrossRef] [PubMed]

38. Ueda, A.; Hamadeh, H.K.; Webb, H.K.; Yamamoto, Y.; Sueyoshi, T.; Afshari, C.A.; Lehmann, J.M.; Negishi, M. Diverse roles of the nuclear orphan receptor CAR in regulating hepatic genes in response to phenobarbital. Mol. Pharmacol. 2002, 61,1-6. [CrossRef]

39. Dong, B.; Saha, P.K.; Huang, W.; Chen, W.; Abu-Elheiga, L.A.; Wakil, S.J.; Stevens, R.D.; Ilkayeva, O.; Newgard, C.B.; Chan, L.; et al. Activation of nuclear receptor CAR ameliorates diabetes and fatty liver disease. Proc. Natl. Acad. Sci. USA 2009, 106, 18831-18836. [CrossRef]

40. Gao, J.; He, J.; Zhai, Y.; Wada, T.; Xie, W. The constitutive androstane receptor is an anti-obesity nuclear receptor that improves insulin sensitivity. J. Biol. Chem. 2009, 284, 25984-25992. [CrossRef]

41. Masuyama, H.; Hiramatsu, Y. Treatment with a constitutive androstane receptor ligand ameliorates the signs of preeclampsia in high-fat diet-induced obese pregnant mice. Mol. Cell. Endocrinol. 2012, 348, 120-127. [CrossRef] [PubMed]

42. Matsuzaki, H.; Daitoku, H.; Hatta, M.; Tanaka, K.; Fukamizu, A. Insulin-induced phosphorylation of FKHR (Foxo1) targets to proteasomal degradation. Proc. Natl. Acad. Sci. USA 2003, 100, 11285-11290. [CrossRef] [PubMed]

43. Kodama, S.; Koike, C.; Negishi, M.; Yamamoto, Y. Nuclear receptors CAR and PXR cross talk with FOXO1 to regulate genes that encode drug-metabolizing and gluconeogenic enzymes. Mol. Cell. Biol. 2004, 24, 7931-7940. [CrossRef] [PubMed]

44. Kazantseva, Y.A.; Yarushkin, A.A.; Pustylnyak, V.O. CAR-mediated repression of Foxo1 transcriptional activity regulates the cell cycle inhibitor p21 in mouse livers. Toxicology 2014, 321, 73-79. [CrossRef] [PubMed]

45. Yoon, J.C.; Puigserver, P.; Chen, G.; Donovan, J.; Wu, Z.; Rhee, J.; Adelmant, G.; Stafford, J.; Kahn, C.R.; Granner, D.K.; et al. Control of hepatic gluconeogenesis through the transcriptional coactivator PGC-1. Nature 2001, 413, 131-138. [CrossRef] [PubMed] 
46. Puigserver, P.; Rhee, J.; Donovan, J.; Walkey, C.J.; Yoon, J.C.; Oriente, F.; Kitamura, Y.; Altomonte, J.; Dong, H.; Accili, D.; et al. Insulin-regulated hepatic gluconeogenesis through FOXO1-PGC-1alpha interaction. Nature 2003, 423, 550-555. [CrossRef]

47. Gao, J.; Yan, J.; Xu, M.; Ren, S.; Xie, W. CAR Suppresses Hepatic Gluconeogenesis by Facilitating the Ubiquitination and Degradation of PGC1 $\alpha$. Mol. Endocrinol. 2015, 29, 1558-1570. [CrossRef]

48. Odom, D.T.; Zizlsperger, N.; Gordon, D.B.; Bell, G.W.; Rinaldi, N.J.; Murray, H.L.; Volkert, T.L.; Schreiber, J.; Rolfe, P.A.; Gifford, D.K.; et al. Control of pancreas and liver gene expression by HNF transcription factors. Science 2004, 303, 1378-1381. [CrossRef]

49. Miao, J.; Fang, S.; Bae, Y.; Kemper, J.K. Functional inhibitory cross-talk between constitutive androstane receptor and hepatic nuclear factor-4 in hepatic lipid/glucose metabolism is mediated by competition for binding to the DR1 motif and to the common coactivators, GRIP-1 and PGC-1alpha. J. Biol. Chem. 2006, 281, 14537-14546. [CrossRef]

50. Kachaylo, E.M.; Yarushkin, A.A.; Pustylnyak, V.O. Constitutive androstane receptor activation by 2,4,6-triphenyldioxane-1,3 suppresses the expression of the gluconeogenic genes. Eur. J. Pharmacol. 2012, 679, 139-143. [CrossRef]

51. Yarushkin, A.A.; Kachaylo, E.M.; Pustylnyak, V.O. The constitutive androstane receptor activator 4-[(4R,6R)-4,6-diphenyl-1,3-dioxan-2-yl]-N,N-dimethylaniline inhibits the gluconeogenic genes PEPCK and G6Pase through the suppression of HNF4 $\alpha$ and FOXO1 transcriptional activity. Br. J. Pharmacol. 2013, 168, 1923-1932. [CrossRef] [PubMed]

52. Lukowicz, C.; Ellero-Simatos, S.; Régnier, M.; Oliviero, F.; Lasserre, F.; Polizzi, A.; Montagner, A.; Smati, S.; Boudou, F.; Lenfant, F.; et al. Dimorphic metabolic and endocrine disorders in mice lacking the constitutive androstane receptor. Sci. Rep. 2019, 9, 20169. [CrossRef] [PubMed]

53. Ledda-Columbano, G.M.; Pibiri, M.; Concas, D.; Molotzu, F.; Simbula, G.; Cossu, C.; Columbano, A. Sex difference in the proliferative response of mouse hepatocytes to treatment with the CAR ligand, TCPOBOP. Carcinogenesis 2003, 24, 1059-1065. [CrossRef] [PubMed]

54. Columbano, A.; Simbula, M.; Pibiri, M.; Perra, A.; Pisanu, A.; Uccheddu, A.; Ledda-Columbano, G.M. Potential utility of xenobiotic mitogens in the context of liver regeneration in the elderly and living-related transplantation. Lab. Investig. 2008, 88, 408-415. [CrossRef]

55. Kazantseva, Y.A.; Pustylnyak, Y.A.; Pustylnyak, V.O. Role of Nuclear Constitutive Androstane Receptor in Regulation of Hepatocyte Proliferation and Hepatocarcinogenesis. Biochemistry (Mosc) 2016, 81, 338-347. [CrossRef]

56. Costa, R.H.; Kalinichenko, V.V.; Tan, Y.; Wang, I.C. The CAR nuclear receptor and hepatocyte proliferation. Hepatology 2005, 42, 1004-1008. [CrossRef]

57. Tschuor, C.; Kachaylo, E.; Limani, P.; Raptis, D.A.; Linecker, M.; Tian, Y.; Herrmann, U.; Grabliauskaite, K.; Weber, A.; Columbano, A.; et al. Constitutive androstane receptor (Car)-driven regeneration protects liver from failure following tissue loss. J. Hepatol. 2016, 65, 66-74. [CrossRef]

58. Blanco-Bose, W.E.; Murphy, M.J.; Ehninger, A.; Offner, S.; Dubey, C.; Huang, W.; Moore, D.D.; Trumpp, A. C-Myc and its target FoxM1 are critical downstream effectors of constitutive androstane receptor (CAR) mediated direct liver hyperplasia. Hepatology 2008, 48, 1302-1311. [CrossRef]

59. Shizu, R.; Shindo, S.; Yoshida, T.; Numazawa, S. MicroRNA-122 down-regulation is involved in phenobarbital-mediated activation of the constitutive androstane receptor. PLoS ONE 2012, 7, e41291. [CrossRef]

60. Lagos-Quintana, M.; Rauhut, R.; Yalcin, A.; Meyer, J.; Lendeckel, W.; Tuschl, T. Identification of tissue-specific microRNAs from mouse. Curr. Biol. 2002, 12, 735-739. [CrossRef]

61. Nakao, K.; Miyaaki, H.; Ichikawa, T. Antitumor function of microRNA-122 against hepatocellular carcinoma. J. Gastroenterol. 2014, 49, 589-593. [CrossRef] [PubMed]

62. Wang, B.; Hsu, S.H.; Wang, X.; Kutay, H.; Bid, H.K.; Yu, J.; Ganju, R.K.; Jacob, S.T.; Yuneva, M.; Ghoshal, K. Reciprocal regulation of microRNA-122 and c-Myc in hepatocellular cancer: Role of E2F1 and transcription factor dimerization partner 2. Hepatology 2014, 59, 555-566. [CrossRef] [PubMed]

63. Xu, H.; He, J.H.; Xiao, Z.D.; Zhang, Q.Q.; Chen, Y.Q.; Zhou, H.; Qu, L.H. Liver-enriched transcription factors regulate microRNA-122 that targets CUTL1 during liver development. Hepatology 2010, 52, 1431-1442. [CrossRef] [PubMed] 
64. Li, Z.Y.; Xi, Y.; Zhu, W.N.; Zeng, C.; Zhang, Z.Q.; Guo, Z.C.; Hao, D.L.; Liu, G.; Feng, L.; Chen, H.Z.; et al. Positive regulation of hepatic miR-122 expression by HNF4 $\alpha$. J. Hepatol. 2011, 55, 602-611. [CrossRef] [PubMed]

65. Kazantseva, Y.A.; Yarushkin, A.A.; Mostovich, L.A.; Pustylnyak, Y.A.; Pustylnyak, V.O. Xenosensor CAR mediates down-regulation of miR-122 and up-regulation of miR-122 targets in the liver. Toxicol. Appl. Pharmacol. 2015, 288, 26-32. [CrossRef] [PubMed]

66. Yarushkin, A.A.; Mazin, M.E.; Pustylnyak, Y.A.; Prokopyeva, E.A.; Pustylnyak, V.O. Promotion of liver growth by CAR is accompanied by Akt pathway activation and FoxM1-Nedd4-mediated repression of PTEN. Arch. Biochem. Biophys. 2019, 672, 108065. [CrossRef]

67. Yarushkin, A.A.; Mazin, M.E.; Yunusova, A.Y.; Korchagina, K.V.; Pustylnyak, Y.A.; Prokopyeva, E.A.; Pustylnyak, V.O. CAR-mediated repression of Cdkn1a(p21) is accompanied by the Akt activation. Biochem. Biophys. Res. Commun. 2018, 504, 361-366. [CrossRef]

68. Yamamoto, Y.; Moore, R.; Goldsworthy, T.L.; Negishi, M.; Maronpot, R.R. The orphan nuclear receptor constitutive active/androstane receptor is essential for liver tumor promotion by phenobarbital in mice. Cancer Res. 2004, 64, 7197-7200. [CrossRef]

69. Dong, B.; Lee, J.S.; Park, Y.Y.; Yang, F.; Xu, G.; Huang, W.; Finegold, M.J.; Moore, D.D. Activating CAR and $\beta$-catenin induces uncontrolled liver growth and tumorigenesis. Nat. Commun. 2015, 6, 5944. [CrossRef]

70. Sidaway, J.E.; Orton, T.C.; Kalaitzi, K.; Jones, H.B.; Foster, A.; Lake, B.G. Analysis of $\beta$-catenin gene mutations and gene expression in liver tumours of $\mathrm{C} 57 \mathrm{BL} / 10 \mathrm{~J}$ mice produced by chronic administration of sodium phenobarbital. Toxicology 2020, 430, 152343. [CrossRef]

71. Yarushkin, A.A.; Mazin, M.E.; Pustylnyak, Y.A.; Prokopyeva, E.A.; Pustylnyak, V.O. Activation of the Akt pathway by a constitutive androstane receptor agonist results in $\beta$-catenin activation. Eur. J. Pharmacol. 2020, 879, 173135. [CrossRef] [PubMed]

72. Yoshinari, K. Role of Nuclear Receptors PXR and CAR in Xenobiotic-Induced Hepatocyte Proliferation and Chemical Carcinogenesis. Biol. Pharm. Bull. 2019, 42, 1243-1252. [CrossRef] [PubMed]

73. Shizu, R.; Yoshinari, K. Nuclear receptor CAR-mediated liver cancer and its species differences. Expert Opin. Drug Metab. Toxicol. 2020, 16, 343-351. [CrossRef]

(C) 2020 by the authors. Licensee MDPI, Basel, Switzerland. This article is an open access article distributed under the terms and conditions of the Creative Commons Attribution (CC BY) license (http://creativecommons.org/licenses/by/4.0/). 